\title{
THYROID HYPERPLASIA PRODUCED IN CHICKENS BY ULTRAVIOLET LIGHT DEFICIENCY
}

\author{
BY KENNETH B. TURNER AND ETHEL M. BENEDICT
}

(From the Department of Medicine of the College of Physicians and Surgeons, Columbia University, and the Presbyterian Hospital, New York City)

(Received for publication April 8, 1932)

In the course of an experiment designed to produce enlargement of the parathyroid glands of chickens by excluding ultraviolet light, it was noted that the birds were developing thyroid instead of parathyroid hyperplasia. As little reference could be found to the influence of light upon the thyroid gland, it was decided to study further this interesting observation. A portion of this work has already been briefly reported (1).

Sorour (2) found that the thyroids of rats kept in darkness resembled those of patients with Basedow's disease while the glands of rats kept in light were normal. The animals were upon a deficient diet and developed rickets and parathyroid hypertrophy.

Clausen (3) subjected rats to selective radiation with infra-red, and found, in a limited number of animals that were examined, "marked enlargement and hypertrophy of the thyroid gland. Irradiation with ultraviolet, in corresponding litter mates, was found to prevent this hypertrophy whether or not the rat was exposed to infra-red radiation." These rats were also rachitic.

Bergfeld $(4,5)$ in a series of experiments on rats noted that the thyroid glands of the animals kept in darkness showed marked hyperplasia. This did not occur in nearly so marked a degree in animals exposed to daylight. Further analysis showed that the ultraviolet rays with a wave-length below 310 millimicrons were the effective factor in preventing this hyperplasia. Metabolic studies showed no correlation between the histological picture and oxygen consumption. Unilateral cervical sympathectomy did not affect the development of hyperplasia. A further finding of interest was that rats kept in darkness failed to develop hyperplasia of the thyroids if injected with a skin extract prepared from other rats that had received ultraviolet light. Protection was not afforded by a similar skin extract from animals that did not receive ultraviolet. It is not clear from Bergfeld's reports whether or not his rats had rickets.

Rosenkranz (6) in a histological study of the thyroids of cattle confined to stables and rabbits in hutches found a hyperplastic reaction that was not present in grazing cattle or rabbits exposed to the sunlight. 
Keeping young rats in darkness or exposing them to sunlight caused no change in the iodine content of the thyroids or of the skin, according to von Fellenberg (7).

Hess and Smith (8) showed that exposure of rats to excessive ultraviolet radiation or the administration of large amounts of viosterol had no effect upon the endocrine glands including the thyroids.

Sheard and Higgins $(9,10)$ found that chickens receiving no ultraviolet light showed a retardation of growth and hyperplasia of the parathyroid glands. Both effects were more or less prevented by the addition of 2 per cent cod liver oil by weight to the diet. Apparently thyroid hyperplasia did not occur as there is no mention of it in these papers.

In summary, evidence is accumulating suggesting that the absence of ultraviolet light causes thyroid hyperplasia.

\section{PRELIMINARY OBSERVATIONS}

In January, 1929, a group of six-day old Barred Rock chicks was separated into two equal lots, each of which was placed in a pen in the same room. The birds in one pen received diffuse daylight through ordinary window glass and were used as controls. The second pen was covered over with number 48 Pittsburgh amber glass. This glass according to Sheard and Higgins $(9,10)$ transmits about 30 per cent of the visible rays and 50 per cent of the infra-red, while none of the waves of a length less than 360 millimicrons pass through. Spectrographic analysis of the particular sample of glass used by us was obtained through the kindness of Professor Hans T. Clarke. It was found that all rays below 344 millimicrons were excluded by the glass. The diet for both groups of chickens was the same and consisted of a mash containing corn and bone meal, wheat middlings, limestone grit, and salt, to which was added cracked corn and wheat. Cod liver oil was mixed with the grain for the first 45 days.

At frequent intervals after the birds had reached an age of 55 days, a chicken from each lot was selected, weighed, and then killed by the administration of ether. Before death had occurred a specimen of blood was obtained by cardiac puncture. At autopsy the following points were noted: general condition, presence of rachitic deformities, consistency of bones, gross appearance of parathyroid and thyroid glands. These glands were then removed for microscopic study. In a few instances a femur was taken for determination of its calcium and phosphorus content.

A total of 37 chickens was examined. The experiment ended in June, 1929.

General condition. The chickens in both groups were usually well, vigorous, and had good plumage. There was a marked variation in size within each group. The bones of the birds raised under amber glass seemed softer than those of the controls, but except for a twisted sternum 
in a few instances there was no other rachitic deformity. One chicken developed leg weakness.

Weights. Figure 1 shows that the chickens raised under amber glass were smaller than the controls particularly in the later part of the period

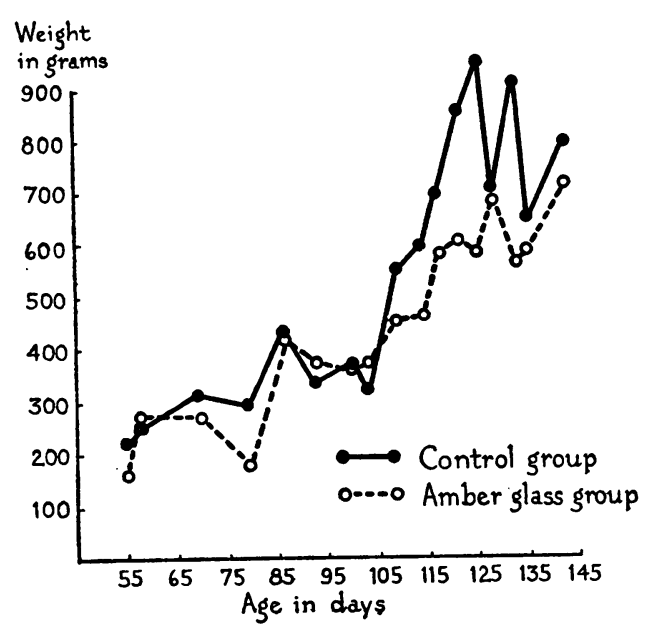

Fig. 1. Weights of Two Groups of Chickens at Different Ages in Preliminary Observations

of observation. The average weights for the entire groups were as follows:

19 chickens raised under amber glass—average weight, 426 grams

18 control chickens -average weight, 535 grams

Serum calcium and phosphorus. The calcium was determined by the method of Clark and Collip (11) and the phosphorus by the method of Fiske and Subbarow (12). A wide variation was noted in both groups as follows:

A. 17 chickens raised under amber glass.

Serum calcium -range: $5.3-12.0 \mathrm{mgm}$. per $100 \mathrm{cc}$.

-average: $9.6 \mathrm{mgm}$.

Serum phosphorus-range: $1.5-8.5 \mathrm{mgm}$. per $100 \mathrm{cc}$.

-average: $4.7 \mathrm{mgm}$.

B. 18 control chickens.

Serum calcium -range: $7.0-12.6 \mathrm{mgm}$. per $100 \mathrm{cc}$.

-average: $10.9 \mathrm{mgm}$.

Serum phosphorus-range: $4.7-8.3 \mathrm{mgm}$. per $100 \mathrm{cc}$. -average: $6.6 \mathrm{mgm}$.

Ackerson, Blish, and Mussehl reported (13) that the average serum calcium in 68 normal chicks was $10.6 \mathrm{mgm}$. and the phosphorus $4.60 \mathrm{mgm}$., 
while in 66 rachitic chicks the calcium averaged $7.49 \mathrm{mgm}$. The phosphorus in both our groups was within normal limits, but the serum calcium of the chickens under amber glass was below the normal average.

Calcium and phosphorus in bone. From each of eight chickens a femur was removed, dried to constant weight, and analyzed for calcium and phosphorus by the same methods used for the serum. The results (Table I) show that the bones of chickens in the amber glass group had a slightly lowered calcium content and a noticeable reduction in phosphorus.

TABLE I

$C a$ and $P$ content of bone and serum

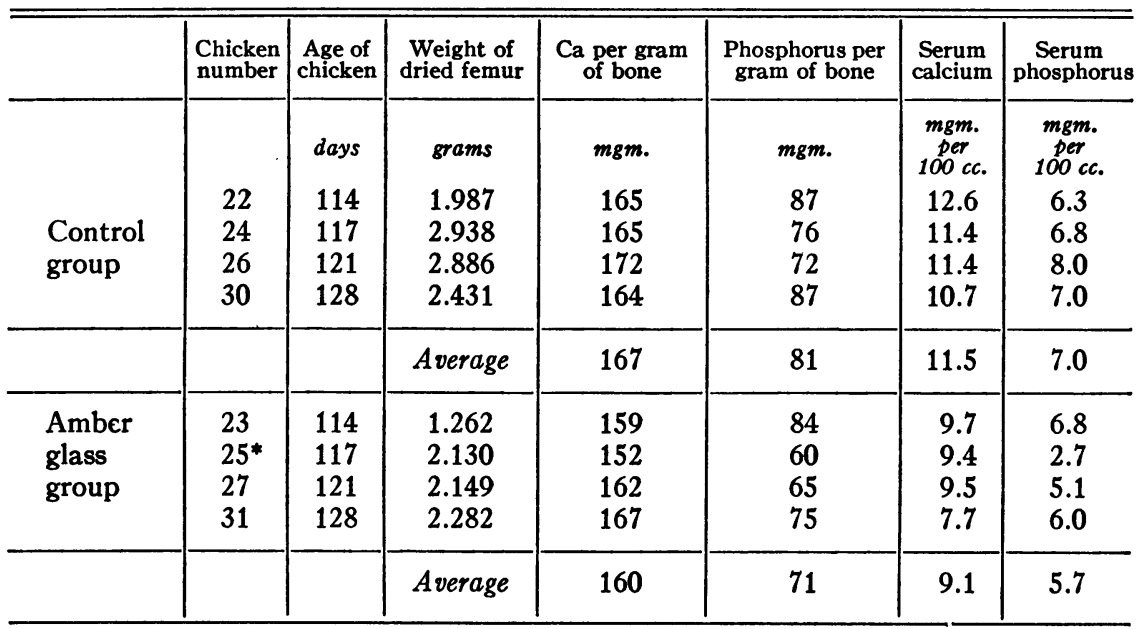

* Despite the low $\mathrm{Ca}$ and $\mathrm{P}$ in both bone and serum this bird was well-developed, healthy and vigorous. The parathyroids were small; the thyroids large and congested.

Thyroid and parathyroid glands. Enlargement of the parathyroids described as slight to moderate, occurred in 6 of the 18 chickens raised under amber glass. In the remainder of the group and in the controls no important variation was noted.

Beginning at the age of 85 days and occurring consistently thereafter a bilateral enlargement of the thyroids, often of marked degree, was found in the chickens of the amber glass group. In addition to being larger than the glands of the control birds, these thyroids were deep purple in color contrasted to yellowish-pink of the normals. Histologically the enlarged thyroids presented the picture of active hyperplasia.

These changes were unexpected and suggested the work described as the first experiment.

Summary of preliminary observations. A group of Barred Rock chicks, raised under amber glass that excluded all rays of wave-lengths less than 344 millimicrons, showed the following differences when compared with a control group that received diffuse daylight through ordinary window 
glass: (1) retardation of growth, (2) lowered serum calcium and phosphorus, (3) softer bones containing less calcium and phosphorus, (4) inconstant parathyroid enlargement, (5) marked enlargement of the thyroid glands.

FIRST EXPERIMENT: THE PRODUCTION OF THYROID HYPERPLASIA BY ULTRAVIOLET LIGHT DEFICIENCY

In order to avoid complicating factors and to render the results as clear-cut as possible certain modifications of the experimental conditions were introduced. Barred Rock chicks were again used. The pens were the same and were indoors as before. The changes were as follows:

1. Because the preliminary mortality among both groups of chickens was apt to be high, it was decided to buy four-week old chicks instead of those newly-hatched. Upon receipt the birds were kept together for a week or ten days. During this period cod-liver oil was added to the diet. At the age of 5 to 6 weeks, the chicks were divided into two lots, one of which was placed in the amber glass pen.

2. The chickens used as controls received ultraviolet radiation for five minutes three times a week by means of a mercury-arc lamp at four feet in addition to diffuse daylight through ordinary window glass.

3. The mash used in the preliminary work was replaced by a commercial growing mash containing oatmeal, hominy feed, yellow hominy feed, barley meal, wheat bran, wheat middlings, fish meal, meat scraps, alfalfa meal, sodium chloride, ground limestone, molasses, and cod liver meal ( 1 per cent by weight). Lettuce or cabbage was also given to both lots two or three times a week.

A total of 58 chickens was used in this experiment. The birds were from three different hatches occurring in February, April and September, 1930. As no variation in response was apparent the results obtained from the three lots have been consolidated for convenience.

General condition. There was no difference in the general condition of the control chickens and those raised under amber glass. The birds were vigorous, healthy, and well-plumaged. There was no evidence of rickets or leg-weakness and the bones of both lots were firm.

Weight. Contrary to the results obtained in the preliminary work, there was no difference between the weights of the controls and of the chickens that received no ultraviolet light (Figure 2). The average body weight of 28 control birds of various ages was 632 grams, while that of 30 chickens raised under amber glass was 630 grams. The close correlation in growth curves is believed to be a result of the constant daily intake of small amounts of cod liver oil.

Serum calcium and phosphorus. Analyses of the calcium and phosphorus content of the serum were made on 6 chickens from each group. 
As no important difference between the two groups was discovered, the determinations were discontinued. The results were as follows:

$\begin{array}{cc}\text { Calcium-Control group } & \text {-range: } 11.1-12.8 \mathrm{mgm} . \\ & \text {-average: } 11.6 \mathrm{mgm} . \\ \text { Ultraviolet deficient group } & \text {-range: } 10.6-13.0 \mathrm{mgm} . \\ & \text {-average: } 11.5 \mathrm{mgm} . \\ \text { Phosphorus-Control group } & \text {-range: } 6.3-8.0 \mathrm{mgm} . \\ & \text { average: } 6.8 \mathrm{mgm} . \\ \text { Ultraviolet deficient group-range: } 5.7-6.9 \mathrm{mgm} . \\ \\ \\ \text {-average: } 6.3 \mathrm{mgm} .\end{array}$

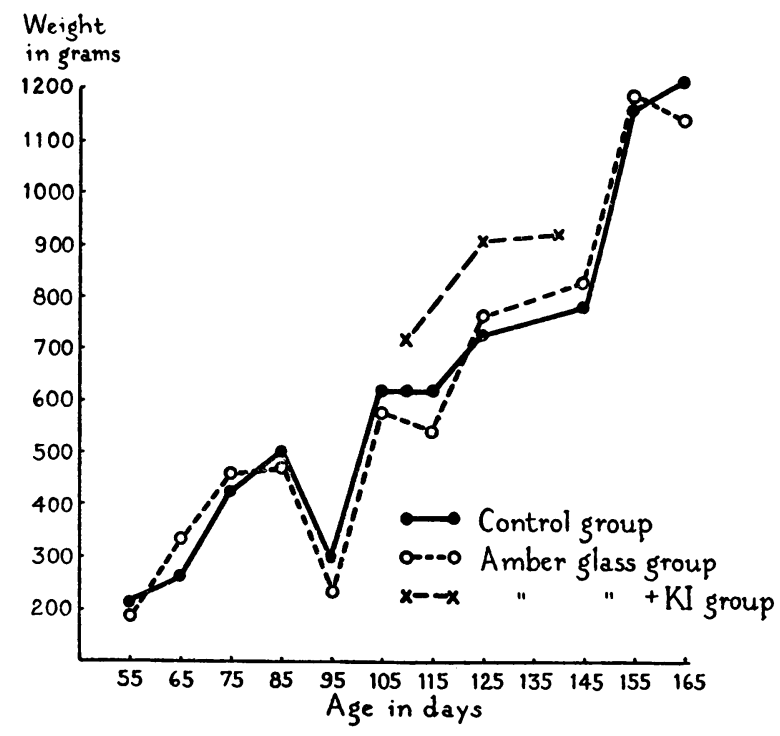

Fig. 2. Body Weights of Chickens at Various Ages in First and Second EXPERIMENTS

Parathyroid glands. There was no consistent variation in the size of the parathyroids. These glands were mostly very small although slight enlargement was an occasional finding. Since this was as frequent in the control group as in the chickens under amber glass, it was considered of no significance.

Thyroid glands. After examination in situ the thyroids were removed and carefully cleared of surrounding tissues by dissection. The two glands of each bird were weighed together and then placed in Bouin's solution in preparation for histological study. The thyroids of the ultraviolet deficient chickens were almos't invariably larger than the glands of the controls of a similar age (Figure 3), ranging in weight from 11-402 $\mathrm{mgm}$. with an average of $102 \mathrm{mgm}$., while those of the controls ranged 
from 7-107 mgm. and averaged $46 \mathrm{mgm}$. More complete details for the entire series of 58 chickens are shown in Table II which gives the age, body weight in grams, thyroid weights in milligrams, and milligrams of

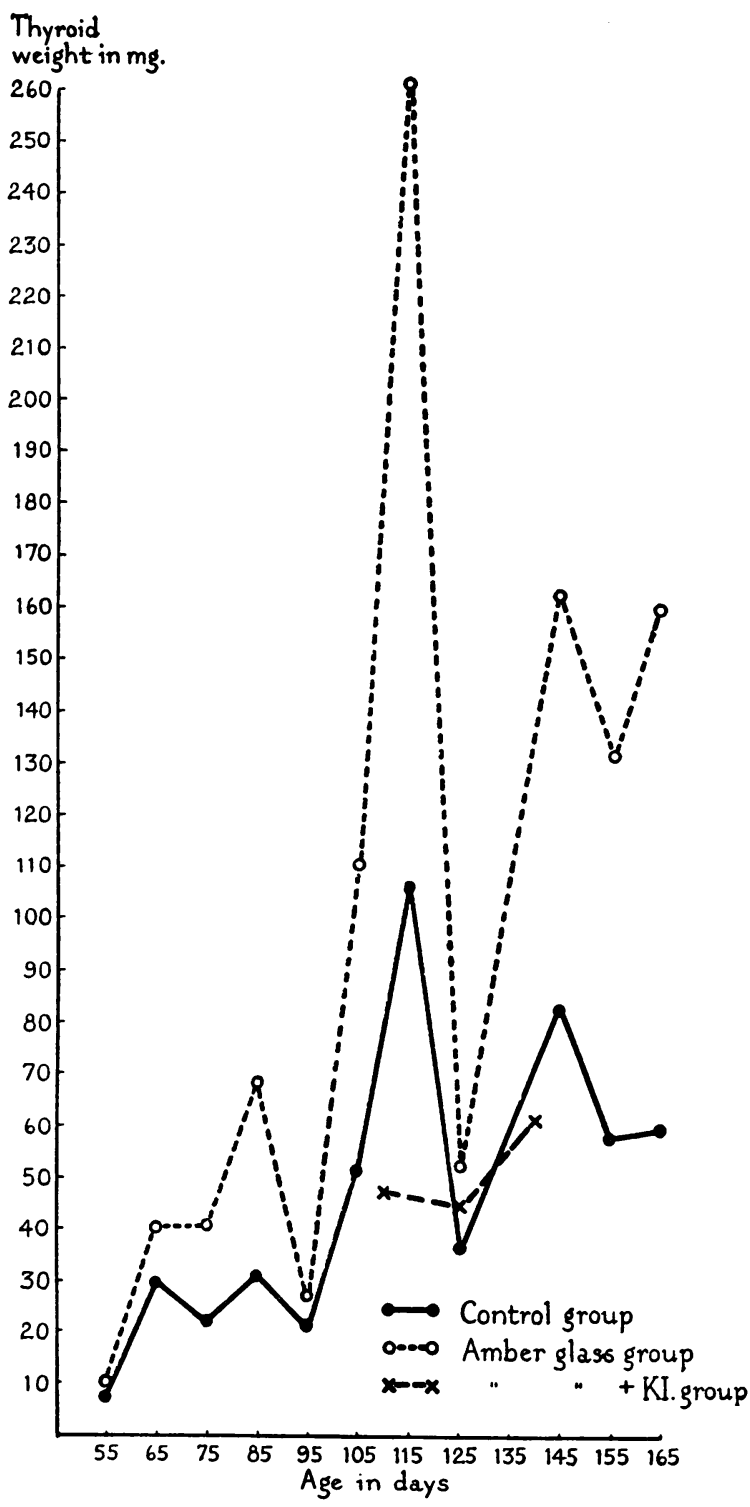

Fig. 3. Variations in Thyroid Weights

thyroid per kilogram of body weight. This last item is of particular interest because of the close correspondence of body weights in the two groups. The variation in the thyroid-body weight ratio as expressed in 
TABLE II

Thyroid and body weights

\begin{tabular}{|c|c|c|c|c|c|c|}
\hline \multirow[b]{2}{*}{ Age } & \multicolumn{3}{|c|}{28 control chickens } & \multicolumn{3}{|c|}{30 ultraviolet deficient chickens } \\
\hline & $\begin{array}{c}\text { Body } \\
\text { weight }\end{array}$ & $\begin{array}{l}\text { Weight } \\
\text { of } \\
\text { thyroids }\end{array}$ & $\begin{array}{l}\text { Mgm. thy- } \\
\text { roid per kilo } \\
\text { body weight }\end{array}$ & $\begin{array}{c}\text { Body } \\
\text { weight }\end{array}$ & $\begin{array}{l}\text { Weight } \\
\text { of } \\
\text { thyroids }\end{array}$ & $\begin{array}{l}\text { Mgm. thy- } \\
\text { roid per kilo } \\
\text { body weight }\end{array}$ \\
\hline $\begin{array}{c}\text { days } \\
55\end{array}$ & $\begin{array}{c}\text { grams } \\
210\end{array}$ & $\begin{array}{r}m g m . \\
7\end{array}$ & $\begin{array}{c}m g m . \\
33\end{array}$ & $\begin{array}{r}\text { grams } \\
195\end{array}$ & $\begin{array}{c}m g m . \\
11\end{array}$ & $\begin{array}{c}m g m . \\
56\end{array}$ \\
\hline 65 & $\begin{array}{l}170 \\
340\end{array}$ & $\begin{array}{l}26 \\
33\end{array}$ & $\begin{array}{r}153 \\
97\end{array}$ & $\begin{array}{l}290 \\
390\end{array}$ & $\begin{array}{l}43 \\
39\end{array}$ & $\begin{array}{l}148 \\
100\end{array}$ \\
\hline 75 & $\begin{array}{l}360 \\
450 \\
500\end{array}$ & $\begin{array}{l}16 \\
31 \\
22\end{array}$ & $\begin{array}{l}44 \\
69 \\
44\end{array}$ & $\begin{array}{l}320 \\
540 \\
510\end{array}$ & $\begin{array}{l}20 \\
53 \\
52\end{array}$ & $\begin{array}{r}63 \\
98 \\
102\end{array}$ \\
\hline 85 & $\begin{array}{l}740 \\
540 \\
450 \\
400 \\
375\end{array}$ & $\begin{array}{l}31 \\
48 \\
24 \\
27 \\
29\end{array}$ & $\begin{array}{l}42 \\
89 \\
53 \\
67 \\
77\end{array}$ & $\begin{array}{l}610 \\
440 \\
430 \\
550 \\
325\end{array}$ & $\begin{array}{r}40 \\
158 \\
27 \\
30 \\
91\end{array}$ & $\begin{array}{r}66 \\
359 \\
63 \\
55 \\
280\end{array}$ \\
\hline 95 & $\begin{array}{l}250 \\
470\end{array}$ & $\begin{array}{l}16 \\
28\end{array}$ & $\begin{array}{l}64 \\
60\end{array}$ & $\begin{array}{l}190 \\
300\end{array}$ & $\begin{array}{l}28 \\
25\end{array}$ & $\begin{array}{r}147 \\
83\end{array}$ \\
\hline 105 & $\begin{array}{l}622 \\
550 \\
770 \\
720 \\
510\end{array}$ & $\begin{array}{l}61 \\
55 \\
62 \\
55 \\
34\end{array}$ & $\begin{array}{r}98 \\
100 \\
81 \\
76 \\
67\end{array}$ & $\begin{array}{l}305 \\
750 \\
710 \\
600 \\
570\end{array}$ & $\begin{array}{r}235 \\
135 \\
41 \\
46 \\
100\end{array}$ & $\begin{array}{r}770 \\
180 \\
58 \\
77 \\
176\end{array}$ \\
\hline 115 & 635 & 107 & 169 & $\begin{array}{l}645 \\
450\end{array}$ & $\begin{array}{l}120 \\
402\end{array}$ & $\begin{array}{l}186 \\
893\end{array}$ \\
\hline 125 & $\begin{array}{l}720 \\
740\end{array}$ & $\begin{array}{l}34 \\
41\end{array}$ & $\begin{array}{l}47 \\
55\end{array}$ & $\begin{array}{l}650 \\
880\end{array}$ & $\begin{array}{l}40 \\
65\end{array}$ & $\begin{array}{l}62 \\
74\end{array}$ \\
\hline 145 & $\begin{array}{l}885 \\
725 \\
755\end{array}$ & $\begin{array}{l}68 \\
89 \\
94\end{array}$ & $\begin{array}{r}77 \\
123 \\
125\end{array}$ & $\begin{array}{l}820 \\
765 \\
905\end{array}$ & $\begin{array}{l}119 \\
190 \\
180\end{array}$ & $\begin{array}{l}145 \\
248 \\
199\end{array}$ \\
\hline 155 & 1160 & 57 & 49 & 1185 & 132 & 111 \\
\hline 165 & $\begin{array}{r}1280 \\
930 \\
1435\end{array}$ & $\begin{array}{l}74 \\
48 \\
59\end{array}$ & $\begin{array}{l}58 \\
52 \\
41\end{array}$ & $\begin{array}{l}1260 \\
1050 \\
1090 \\
1165\end{array}$ & $\begin{array}{l}226 \\
164 \\
105 \\
144\end{array}$ & $\begin{array}{r}179 \\
156 \\
96 \\
132\end{array}$ \\
\hline Average & 632 & 46 & 75 & 630 & 102 & 179 \\
\hline
\end{tabular}

milligrams of thyroid per kilogram of chicken ranged from 33-169 mgm. and averaged $75 \mathrm{mgm}$. for the controls, while in the ultraviolet deficient group the range was $56-893 \mathrm{mgm}$. and the average $179 \mathrm{mgm}$. 


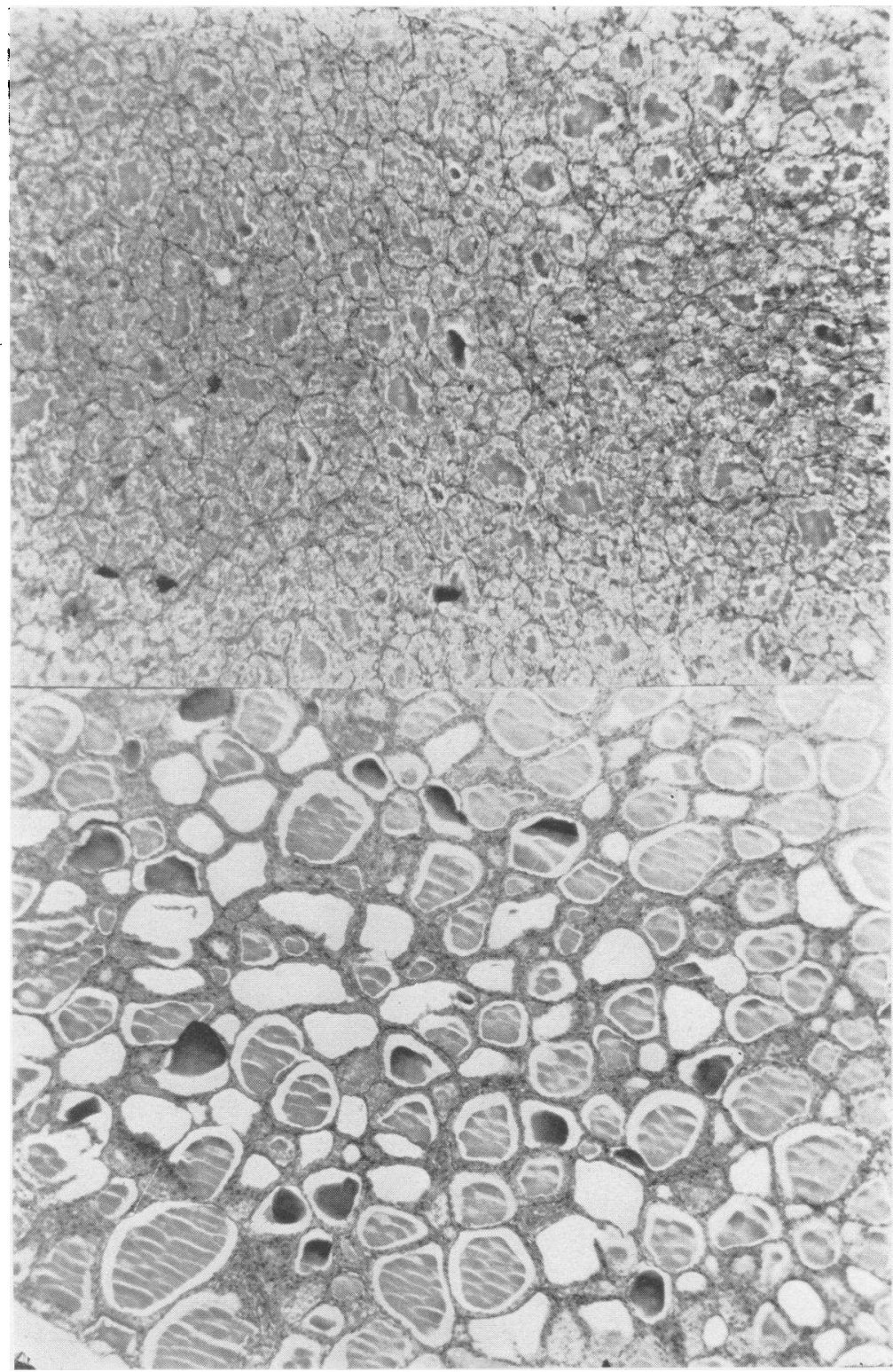

FIG. 4

At the bottom, thyroid from a control chicken that received ultraviolet light. The follicles are large and well filled with colloid. The epithelial cells are cuboidal. The upper section is from a chicken of the same age and weight that was deprived of ultraviolet light. Hyperplasia of the epithelial cells is evident. The follicles are more numerous and smaller. The amount of colloid is decreased. The oxygen consumption of both birds was the same. (Nagnification $\times 200$.) 


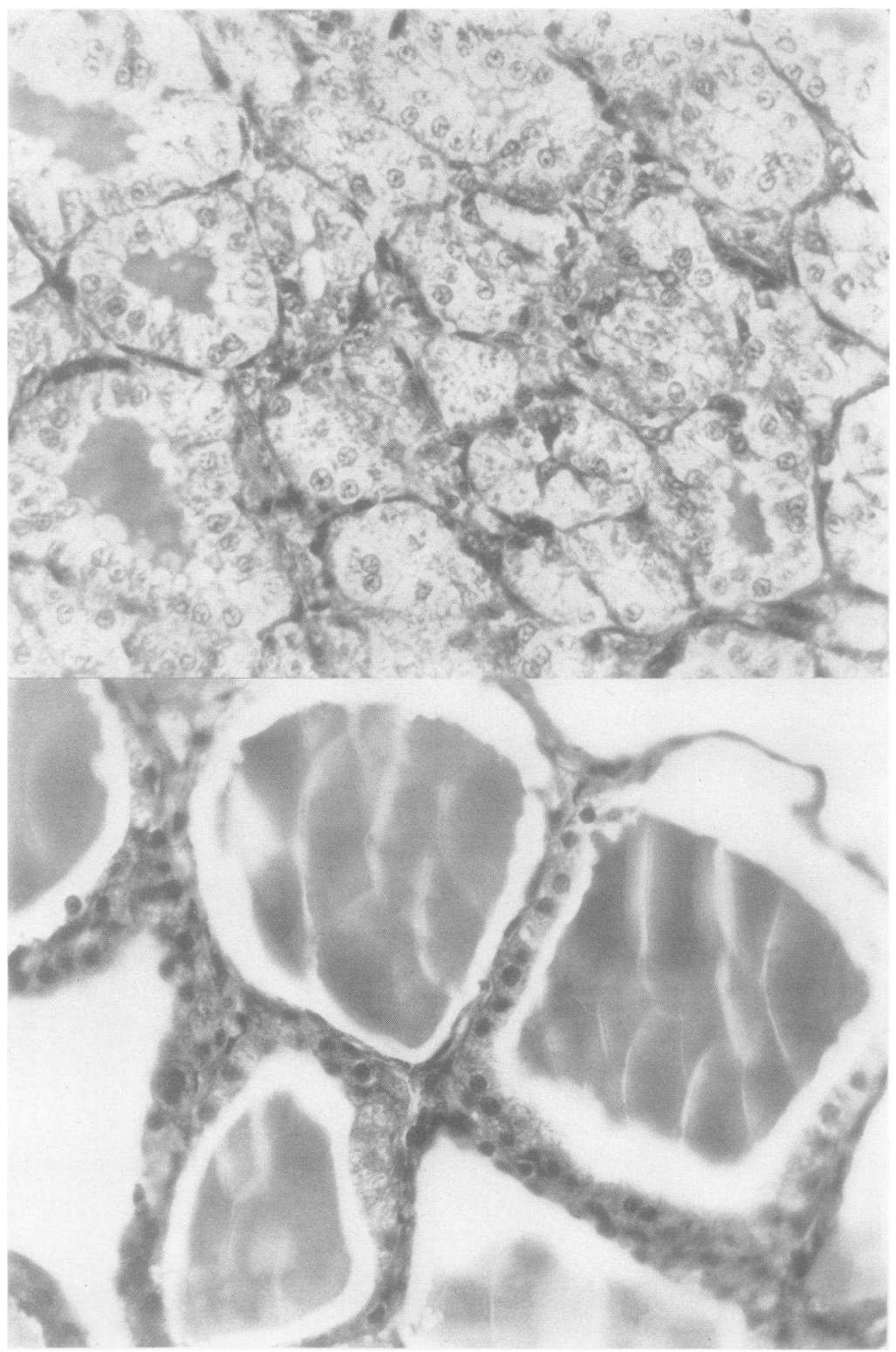

Fili. 5. Higher Maginfication of Same Glandos Show in Figure 4

The epithelial cells in the thyroid from the control chicken are cuboidal; those in the thyroid of the ultraviolet deficient chicken are cylindrical, hazy in outline, and contain many small globules. $(\times 800$. $)$ 
In addition to gross enlargement, there was a marked difference in color. Whereas the normal gland was a pale, yellowish pink, the enlarged glands were usually deep, purplish red and gave the impression of increased vascularity.

The histological differences are well shown in Figures 4 and 5. In the thyroids of the control group the epithelial cells were low cuboidal, the follicles were large, and colloid was abundant and readily stained. The enlarged glands of the ultraviolet deficient chickens showed very marked hyperplasia of the epithelial cells which were more cylindrical in form, smaller and more abundant follicles, and a great diminution in the amount of colloid. The colloid that was present stained poorly. There was no lymphocytic infiltration.

Oxygen consumption. Through the kindness of Dr. Dickinson W. Richards, Jr., who supervised this part of the experiment, it was possible to determine the oxygen consumption of four chickens from each group (Table III). In spite of the fact that the ultraviolet deficient chickens

TABLE III

Oxygen consumption compared with size of thyroids

\begin{tabular}{l|c|c|c|c}
\hline \hline & $\begin{array}{c}\text { Chicken } \\
\text { number }\end{array}$ & $\begin{array}{c}\text { Number of } \\
\text { metabolism } \\
\text { determinations }\end{array}$ & $\begin{array}{c}\text { Average } \mathrm{O}_{2} \text { consumption } \\
\text { per gram of chicken } \\
\text { per minute }\end{array}$ & $\begin{array}{c}\text { Thyroids in mgm. per kgm. } \\
\text { body weight }\end{array}$ \\
\hline & 64 & 3 & $c c$. & mgm. \\
Control & 65 & 7 & 1.07 & 55 \\
group & 66 & 3 & 1.07 & 77 \\
& 67 & 4 & 0.96 & 49 \\
& & Average & 0.82 & 58 \\
\hline Ultraviolet & $64 \mathrm{~A}$ & 4 & 0.98 & 60 \\
deficient & $65 \mathrm{~A}$ & 3 & 0.91 & 74 \\
group & $66 \mathrm{~A}$ & 6 & 0.93 & 145 \\
& $67 \mathrm{~A}$ & 3 & 1.02 & 179 \\
\hline & & Average & 0.87 & 127 \\
\hline
\end{tabular}

had twice as much thyroid tissue per kilogram of body weight as the controls, the oxygen consumption displayed no significant variation, showing that the hyperplasia was a compensatory process and that the enlarged gland was not an overacting one.

Iodine content of ihyroids. Iodine determinations were made upon three glands by Dr. Alexander B. Gutman to whom we are indebted for the figures shown in Table IV. The results suggest that the iodine content of the hyperplastic gland was low.

Summary. (1) A group of chickens raised under amber glass that excluded all the ultraviolet rays below 344 millimicrons was compared 
TABLE IV

Iodine content of thyroids

\begin{tabular}{|c|c|c|c|c|c|}
\hline & $\begin{array}{l}\text { Chicken } \\
\text { number }\end{array}$ & $\begin{array}{l}\text { Weight fresh } \\
\text { gland }\end{array}$ & $\begin{array}{l}\text { Weight dried } \\
\text { gland }\end{array}$ & $\begin{array}{l}\text { Per cent iodine } \\
\text { in dried gland }\end{array}$ & $\begin{array}{l}\text { Total iodine } \\
\text { content }\end{array}$ \\
\hline $\begin{array}{l}\text { Control } \\
\text { group }\end{array}$ & $\begin{array}{l}68 \\
69\end{array}$ & $\begin{array}{l}m g m . \\
28.0 \\
32.0\end{array}$ & $\begin{array}{c}m g m . \\
6.4 \\
8.0\end{array}$ & $\begin{array}{l}0.353 \\
0.747\end{array}$ & $\begin{array}{c}m g m . \\
0.023 \\
0.059\end{array}$ \\
\hline $\begin{array}{l}\text { Ultraviolet } \\
\text { deficient } \\
\text { group }\end{array}$ & $68 \mathrm{~A}$ & 79.0 & 16.3 & 0.084 & 0.014 \\
\hline
\end{tabular}

with a similar group that received ultraviolet radiation. (2) Rickets was prevented by the inclusion of 1 per cent cod liver meal in the diet of both groups. (3) The growth curves of the two lots corresponded. (4) No significant variation in the parathyroid glands was apparent. (5) The thyroids of the ultraviolet deficient chickens were grossly enlarged, hyperplastic, and in one instance, low in iodine. (6) Despite the thyroid enlargement these chickens showed no increase in oxygen consumption.

SECOND EXPERIMENT: THE EFFECT OF IODINE UPON THE DEVELOPMENT OF THYROID HYPERPLASIA PRODUCED BY ULTRAVIOLET LIGHT DEFICIENCY

It seemed desirable to determine what effect the administration of large amounts of iodine would have upon the development of the thyroid hyperplasia that appeared in chickens deprived of ultraviolet light. Accordingly 11 Barred Rock chicks at the age of five weeks were placed under amber glass in April, 1931. The diet was the same as in the previous experiment but a liberal quantity of saturated solution of potassium iodide was added to the drinking water daily. It was impossible to determine the iodine intake of each chicken but it was felt that this procedure assured the consumption of far greater than the usual amounts of iodine.

The chickens were killed between the ages of 110 and 140 days. Experience with previous lots of chickens raised under amber glass had shown that in this period maximal enlargement of the thyroids might be expected.

The body and thyroid weights are given in Table V. By referring again to Figures 2 and 3 it is seen that the body weights were above the average for control birds of similar ages, and, more particularly, that the thyroid weights were comparable to those of the controls that received adequate ultraviolet radiation. Moreover the histological picture of the thyroid also resembled that of the control chickens (Figs. 4 and 5).

A comparison of the three groups of chickens (controls, ultraviolet deficient, and ultraviolet deficient fed potassium iodide) is shown in 
TABLE V

Body and thyroid weights of ultraviolet deficient chickens receiving excessive amounts of iodine

\begin{tabular}{c|c|c|c}
\hline \hline Age & $\begin{array}{c}\text { Body } \\
\text { weight }\end{array}$ & $\begin{array}{c}\text { Thyroid } \\
\text { weights }\end{array}$ & $\begin{array}{c}\text { Mgm. thyroid per } \\
\text { kgm. body weight }\end{array}$ \\
\cline { 2 - 4 } days & grams & mgm. & mgm. \\
111 & 876 & 47 & 54 \\
111 & 773 & 60 & 78 \\
111 & 509 & 23 & 45 \\
111 & 674 & 60 & 89 \\
124 & 1290 & 68 & 53 \\
124 & 685 & 30 & 44 \\
124 & 890 & 41 & 46 \\
124 & 781 & 41 & 53 \\
140 & 938 & 83 & 89 \\
140 & 910 & 49 & 54 \\
140 & 943 & 50 & 53 \\
\hline Average & 843 & 56 & 60 \\
\hline
\end{tabular}

Table VI which serves as a partial resume of the work. The average body weight of the controls and the ultraviolet deficient chickens is strikingly similar. The ultraviolet deficient group fed $\mathrm{KI}$ cannot be included in this comparison because there were no chickens less than 110 days old in this group, which also accounts for the slightly increased thyroid weights of

TABLE VI

Summary of body and thyroid weights for the three groups of chickens

\begin{tabular}{|c|c|c|c|c|}
\hline Group & $\begin{array}{l}\text { Number of } \\
\text { chickens } \\
\text { used }\end{array}$ & $\begin{array}{c}\text { Average } \\
\text { body } \\
\text { weight }\end{array}$ & $\begin{array}{l}\text { Average } \\
\text { thyroid } \\
\text { weights }\end{array}$ & $\begin{array}{l}\text { Average } \\
\text { mgm. of thy- } \\
\text { roid per kgm. } \\
\text { body weight }\end{array}$ \\
\hline & & grams & mgm. & mgm. \\
\hline Controls......... & 28 & 632 & 46 & 75 \\
\hline Ultraviolet deficient . . . . . . & 30 & 630 & 102 & 179 \\
\hline Ultraviolet deficient fed KI . . . & 11 & $(843)$ & 56 & 60 \\
\hline
\end{tabular}

these birds. The thyroid glands of the chickens raised under amber glass without the addition of iodine to the diet are more than twice the weight of the control glands. This difference again appears when the results are expressed as milligrams of thyroid per kilogram of body weight. In this last comparison the iodine-fed birds closely resemble the controls.

\section{CONCLUSIONS}

Enlargement of the thyroid glands of growing, non-rachitic chickens may be produced by the exclusion of ultraviolet light. Histologically the glands are hyperplastic, and poor in colloid. The thyroid enlargement is not accompanied by an increase in the bird's oxygen consumption. The hyperplasia may be prevented by the administration of potassium iodide. 


\section{BIBLIOGRAPHY}

1. Turner, K. B., Proc. Soc. Exp. Biol. and Med., 1930, xxviii, 204. Thyroid Hyperplasia Produced in Chickens by Ultraviolet Light Deficiency.

2. Sorour, M. F., Beitr. z. path. Anat., 1923, lxxi, 467. Versuche über Einfluss von Nahrung; Licht und Bewegung auf Knochenentwicklung und endokrine Drüsen junger Ratten mit besonderer Berücksichtigung der Rachitis.

3. Clausen, E. M. L., Proc. Soc. Exp. Biol. and Med., 1928, xxvi, 77. Effect of Infra-red Radiation on Growth of Rachitic Rat.

4. Bergfeld, W., Endokrinologie, 1930, vi, 269. Der Einfluss des Tageslichtes auf die Rattenschilddrüse mit Berücksichtigung des Grundumsatzes.

5. Bergfeld, W., Strahlentherapie, 1930-31, xxxix, 245. Über die Einwirkung des ultravioletten Sonnen- und Himmelslichtes auf die Rattenschilddrüse mit Berücksichtigung des Grundumsatzes.

6. Rosenkranz, G., Klin. Wchnschr., 1931, x, 1022. Einfluss des ultravioletten Sonnen- und Himmelslichtes auf die Schilddrüsen von Kaninchen und Rindern.

7. von Fellenberg, Th., Biochem. Ztschr., 1931, ccxxxv, 205. Ultraviolettes Licht und Kropf.

8. Hess, A. F., and Smith, P. E., Am. J. Dis. Child., 1931, xli, 775. Excessive Ultraviolet Irradiation. Effect on the Nutrition and the Endocrine Glands of Rats.

9. Sheard, C., and Higgins, G. M., Am. J. Physiol., 1928, lxxxv, 290. The Effects of Selective Solar Irradiation on the Growth and Development of Chicks.

10. Higgins, G. M., and Sheard, C., Am. J. Physiol., 1928, lxxxv, 299. The Effects of Selective Solar Irradiation on the Parathyroid Glands of Chicks.

11. Clark, E. P., and Collip, J. B., J. Biol. Chem., 1925, lxiii, 461. A Study of the Tisdall Method for the Determination of Blood Serum Calcium with a Suggested Modification.

12. Fiske, C. H., and Subbarow, Y., J. Biol. Chem., 1925, Ixvi, 375. The Colorimetric Determination of Phosphorus.

13. Ackerson, C. W., Blish, M. J., and Mussehl, F. E., J. Biol. Chem., 1925, 1xiii, 75. A Study of the Phosphorus, Calcium, and Alkaline Reserve of the Blood Sera of Normal and Rachitic Chicks. 